\title{
Profesinio tapatumo stiprinimo praktika: vilniečių profesinè diena
}

\author{
IRMA ŠIDIŠKIENE் \\ Lietuvos istorijos institutas, Kražių g. 5, LT-01108 Vilnius \\ El. paštas: irmasidiskiene@istorija.It
}

\begin{abstract}
Remiantis lauko tyrimais ir medijoje skelbtų reportažų analize, straipsnyje siekiama išnagrinèti profesinès dienos (šventès idejos ir struktūros) poveikị profesinio tapatumo stiprinimui. Tyrimas rodo, jog standartizuotas šventimas, leidęs apimti platesnị profesijos narių ratą, šventę labiau užtvirtino, o dienos paminejjimas neformaliu lygmeniu, t. y. tarp bendradarbių ir ypač šeimos rate, užtikrino profesinès dienos gyvybingumą. Minejimų datos stipriai susaistytos su ideologija, istorine atmintimi, tačiau tyrimas rodo, kad dabar dauguma vilniečių neakcentuoja, nežino ir visiškai nesidomi, kodèl buvo pasirinkta konkreti data profesinès dienos minejjimui.
\end{abstract}

Raktažodžiai: profesinè diena, profesinis tapatumas, modernios šventės struktūra, modernios šventès data-ideja

\section{IVADAS}

Profesinès dienos minèjimas - tai viena iš naujųjų modernių švenčių, kuri Lietuvoje pradèta švęsti XX a., ji gerai išlikusi ne tik žmonių atmintyje, bet ir šiandien yra dažnai palaikoma, tęsiama organizacijų administracijos, asociacijų, kartais pačių profesijos narių iniciatyva. Straipsnyje nagrinėjama profesinių dienų minèjimo reikšmė tvirtinant (stiprinant) profesinị tapatumą.

Tyrimo objektas - profesinès dienos minejjimas Vilniuje. Tikslas - išnagrinèti švenčių datos-idejos ir iškilmių struktūros (praktikos) ịtaką profesinio tapatumo stiprinimui. Lygindami profesinès dienos šventimą sovietmečiu ir dabar bandysime išsiaiškinti, kaip kito oficialaus ritualo forma ir minèjimo palaikymas bendruomenès neformalia praktika, o norèdami sužinoti, kiek svarbi neformaliam minėjimui oficialioji šventès idèja, - ar profesinès dienos propaganda padeda įsisąmoninti, perimti šventès ideją (ar „kaltininkai“ tampa propagandos subjektu).

Straipsnyje pirmiausia aptariamos tyrimo teorinès prieigos ir literatūra, pirmoje ir antroje dalyje, naudojantis istoriniu lyginamuoju metodu, apžvelgiama profesinès dienos oficialaus minejjimo sovietmečiu ir dabar struktūra ir šios dienos išraiška neformalioje aplinkoje, trečioje dalyje paliečiamas propagandos tezių ir pateikejjų šventès suvokimo santykis.

Tyrime remiuosi konstruktyvistiniu požiūriu: socialinè realybė, institucijos, normos, vertybès, interesai ir tapatumas nèra duoti, bet nuolat kuriami ir palaikomi veikejuc diskursyvinemis ir elgesio praktikomis. Profesinis tapatumas, arba asmens tapatinimasis 
su savo profesija yra toks procesas, pasak Manuelio Castelso, kai profesijos nariai ši tapatumą „internalizuoja bei îprasmina save per tai, ką internalizavę" $[2,23]$, tampa šių pažiūrų, normų ir vertybių nešèjais. Gausi tapatumo tyrimų literatūra, savaime suprantama, diversifikuojasi mokyklų ịvairove. Vienų mokyklų atstovai nagrinėja kognityvinius procesus, kiti - socialines praktikas ir simbolinius ịrankius, su kuriais konstruojama tapatybè. Profesinio tapatumo tyrimuose ypač daug dèmesio pastaruoju metu skirta kognityviniams procesams, t. y. îvairių profesijų mokymosi ir studentų praktikos metu ugdomam profesiniam tapatumui. Mokymosi ir praktikos procese ugdomas profesinis tapatumas mokslininkų dar siejamas su profesine identifikacija. Profesinis tapatumas tyrimuose taip pat yra asocijuojamas su profesijos ir profesionalumo sąvokomis [20, 2], kai profesionalumas suvokiamas kaip ideologija, deklaruojanti svarbų vaidmeni profesijoms ir jų atstovams organizuojant ir teikiant tam tikras prekes ir paslaugas visuomenei. Profesiniai veiksmai atitinka bendrą tikslą, misiją, vertybių sistemą, etikos kodeksą [25, 210]. Mokymosi ir praktikos metu igyjamos profesijos vertybès, misija vèliau yra palaikomos darbovietès ar asociacijos oficialiosios kultūros politikos. Organizacijos kultūra (oficialioji ir neformalioji, pastaroji vadinama subkultūra) ir profesinis tapatumas suprantamas kaip bendra prasmių sistema. Profesinio tapatumo konstravimas yra sąmoningas suaugusio žmogaus gyvenimo procesas, perimant tai profesijai būdingą kultūrą. Dirbantysis stiprina savo profesinị tapatumą tobulindamasis profesijos srityje ir bendraudamas su kolegomis ịvairiomis progomis, pvz., dalyvaudamas darbovietès (ar platesniu mastu - profesijos) susiejimuose, šventėse.

Modernų viešojo gyvenimo ritualizavimą, kartojamus tikslinius socialinius, kultūrinius renginius galima vadinti socialiniais ritualais, kuriais siekiama įtvirtinti naujus socialinius, kultūrinius santykius ir tapatumą. Priklausomai nuo konteksto ritualai yra perkuriami juos kaskart interpretuojant ar sąmoningai sukuriami / išgalvojami ir ịtvirtinami pasitelkus nuolatinio kartojimo mechanizmus. Sąvokos „perkuriami“ ir „sukuriami / išrandami“ (invention) turi skirtingas konotacijas, kai kalbama apie reiškinio, realijos tęstinumą ar lokalaus ritualo autentiškumą, todèl siekiant nusakyti ritualo dinamiškumą ir pabrěžti jo, susiformavusio iš apačios, emocinę, spontanišką esmę, vartojama lankstesnè „išradingumo“ (inventiveness) sąvoka [22, 350]. Tačiau šios sąvokos yra negrynos, persipynusios. Išradingumas taikytinas tradiciniams, autentiškiems ritualams, kurie padeda perimti / perduoti tradicijas ir adaptuoti naujoves, pasikeitusius socialinius santykius. Sąvoka išradimas žymi naujų, modernių švenčių sukūrimo procesą, kurị tirdami mokslininkai atkreipé dèmesị ị galios vaidmenị. Ritualas kaip galia, spontaniškai egzistuojantis bendruomenėje (žr. tyrimus apie čiabuvių kultūrą, socialinę santvarką), tampa konfesinès ir politinès ar kitos galios manipuliacijos objektu. Šių galių ịtakos švenčių kalendoriui stebimos jau nuo pirmųjų konfesijų, politinių darinių atsiradimo, naujaisiais laikais ritualus taip pat naudoja komercinès ir kitos galios. Catherine Bell pažymėjo, jog veiksmingas ritualas gali būti ginčytinas ir pažeidžiamas politinių manipuliacijų ir komercializavimo [1, 252]. Kaskart, pasikeitus politinei galiai, kuriami nauji ritualai (pvz., valstybinès nepriklausomybès šventės, sovietinès Spalio, Pergalès ir kt. šventès) ar transformuojami jau esantys, tradiciniai, pvz., Derliaus šventė sovietinèse šalyse arba „Dožinki“ Lenkijoje [8, 171-192], naujai šventei pritaikomas ịprastas, t. y. buvusios šventès, laikas (data).

Politikos ir komercijos įtaką šventėms, apeigoms plačiai aptaria etnologai, antropologai, pabrèždami jų destruktyvumą ritualo autentiškumo ar dalyvio autentiško, spontaniško santykio su švente atžvilgiu $[9,205]$. Mokslininkai netiki šventės inkorporavimo ir kontroliavimo „iš viršaus“ i apačią veiksmingumu $[23,77]$ - tokia šventė prilyginama dirbtinèms, 
nenatūralioms struktūroms, neautentiškam ritualui [1,227], neaiškus jų išlikimas, tęstinumas (tokios spontaniškai atsiradusios miesto šventès dar vadinamos momentine ar dabarties tradicija - instant tradition) [11]. Be to, ritualo spontaniškumas kaip emocinè vertė etnologų, antropologu yra akcentuojamas ir laikomas siekiamybe naujoms bendruomenèms konstruojant bendrą socialinị tapatumą [23, 67]. Remiantis šiuo požiūriu manoma, jog nauji ritualai ir ịvesti „iš viršaus“ $[1,145]$ tokio spontaniško santykio tiesiog nesukuria. Katarina Ek-Nilsson [4], svarstydama modernios valstybinès vẻliavos šventès sureikšminimą (paskelbus tą dieną laisvadieniu), suabejojo oficialios šventès virtimo spontaniška galimybe. Net ir institucinè šventès apsauga (jos ịtraukimas ị UNESCO nematerialių vertybių apsaugą), Laurent Sébastien Fournier [5] manymu, gali keisti tradicinių švenčių spontaniškumą (autentiškumą). Nauji tyrimai rodo, jog šventė, kuriama komercijos galios, pradžioje būna nenatūrali, dirbtiné, bet yra pavyzdžių, kai ji vèliau tampa populiaria ir „spontaniška“, pvz., Motinos [9] ar Valentino dienos tarp atskirų gyventojų grupių [10]. Komercijos ir vartojimo pozityvumą ritualams įžvelgia Melinda Papp, nagrinejjusi japonų Shichigosan vaikystès ritualą; jos manymu, jie iš tiesų turi turèti teisètą vietą kuriant ritualinę patirtį šiuolaikinių miestų kontekstuose [16].

Suprantama, šventès sukūrimas dar nelaiduoja jos sèkmès ir palaikymo visuomenejje (net ir „autentiškos“ šventès atkūrimas, kaip rodo Lia Zola [26] tyrimas Alpèse). Analizuojant švenčių išradimo ir diegimo procedūrą, buvo išskirtas socialinio ritualo kūrimo modelis, taikytas ir profesinių dienų modeliavimui: 1) pasirenkama data, susaistyta su tam tikrais profesijai svarbiais ịvykiais, žmonèmis, kaip tinkama reprezentuoti profesijai svarbias idejas bei šventès kilmę, kartais priderinta prie ịprastų švenčių laiko (toliau - data-idèja); 2) šventès yra valdžios ar organizacijų institucijos reglamentuotos (kai kurios šių dienų yra ịtrauktos ị atmintinų dienų sąrašą arba asociacijų nuostatus), ritualas vyksta tam tikra nustatyta tvarka, jị sudaro įvairūs iškilmių renginiai; 3) šventei parenkama tinkama vieta (viešosios miesto ar uždaresnès pastatų erdvès); 4) kasmet ji kartojama, taip bendruomenè ipratinama prie šventès, jai pritaikomos aktualijos. Profesinès dienos minejjimas atskleidžia oficialią profesinès organizacijos politiką, o šių švenčių metu diegiamos vertybès yra susietos su profesiniu atsidavimu, pasiaukojimu ir pasididžiavimu. Taip palaikomas profesinis tapatumas.

Kalbant apie sovietmečio naujas šventes, tyrèjams sunkiau suvokti sovietmečio gyventojų naujų švenčių prièmimą ir dalyvavimą jose, nes žmonès atkakliai atskiria tai, ką jie daro ir kuo jie tiki $[1,225]$. Profesinès dienos sovietmečiu buvo kontroliuojamos politinès galios, kuriai darbuotojai negalejo nepaklusti. Dauguma šių švenčių ir posovietmečiu išliko politinès galios įtakoje, todèl daug rašyta apie naujas socialistines šventes, skelbti propagandiniai pranešimai, reportažai iš ịvykusių švenčių, buvo rengiami metodiniai nurodymai. Šiandien ši literatūra yra tyrimo objektas ar šaltinis. Pasirodantys tyrimai apie sovietmečio ir posovietmečio modernias šventes, profesinę kultūrą kartais paliečia ir profesines dienas. Antai T. Ščepanskaja, nagrinėdama profesinès neformaliosios kultūros tradicijas Rusijoje $[29,29]$, neaplenkè profesinių dienų užstalès praktikų [29, 198-201]. Tyrinėdama modernias šventes Aleksandra Frolova [6] atskleidè, kad jas inkorporuojant buvo istoriškai išnagrinètas ir gerai apgalvotas datų parinkimas - jos derintos su senuoju bažnytiniu kalendoriumi. Nemažiau svarbu ir tai, jog profesinès dienos, nors dauguma jų nėra visuotinès, masiškos, įsišaknijo ir diversifikavosi lokaliai. Nagrinėdama naujų oficialių švenčių Baltarusijoje semantiką, charakterizuojančią dabartinès valdžios ideologiją, vertybes, Julija Galinovskaja [27] pabrèžè, kad ten profesinių dienų datos išlaikytos kaip sovietmečio švenčių tąsa. 
Irmos Šidiškienės [21] straipsnyje nagrinètas profesinių švenčių pristatymas istoriografijoje, medijose. Pagal informacijos nuorodų kiekį apie profesines dienas medijose nustatytos populiariausios, iš kurių pasirinktos statutinių organizacijų profesinès dienos, ir atliktas lauko tyrimas - siekta nustatyti, ar šventė suburia profesinę grupę ar ne. Paaiškejjo, jog statutinių pareigybių profesinès dienos nedidina profesijos narių socialinės integracijos plačiąja prasme (tarp atskirų pareigybių) ir skatina diversifikaciją.

Minètos studijos nenustatè, kiek profesinio tapatumo formavimui yra svarbus jo pastovus tvirtinimas praktikoje, tiksliau, šventèje, todèl šiame straipsnyje pagrindinis dèmesys skiriamas profesinių dienų iškilmių struktūros ir propagandos analizei, taip pat datos-idèjos įtakai neformaliajam šventimui.

Tyrimo metu analizuoti medijų pranešimai (sovietinių ir dabartinių) (plačiau žr. [21]) atskleidžia profesinių dienų oficialiosios šventès idejją, jos procesą. Struktūruoti interviu rodo neformalų vilniečių santyki su šia švente. J. Mardosos vadovaujami studentai (1) 2002 m. rinko medžiagą pagal detalų profesinès dienos minejjimo klausimyną [14] ir siekè išsiaiškinti pateikejjų praktiką ir požiūrị, šventès suvokimą. Šio straipsnio autorès klausimyne profesinei dienai buvo skirtas vienas klausimas (2), kuris turejjo atskleisti šventès vietą bendradarbių laisvalaikio kontekste. Interviu metu teko išplèsti ši klausimą ir patikslinti, ką respondentai žino apie šventès ir jos datos prasmę.

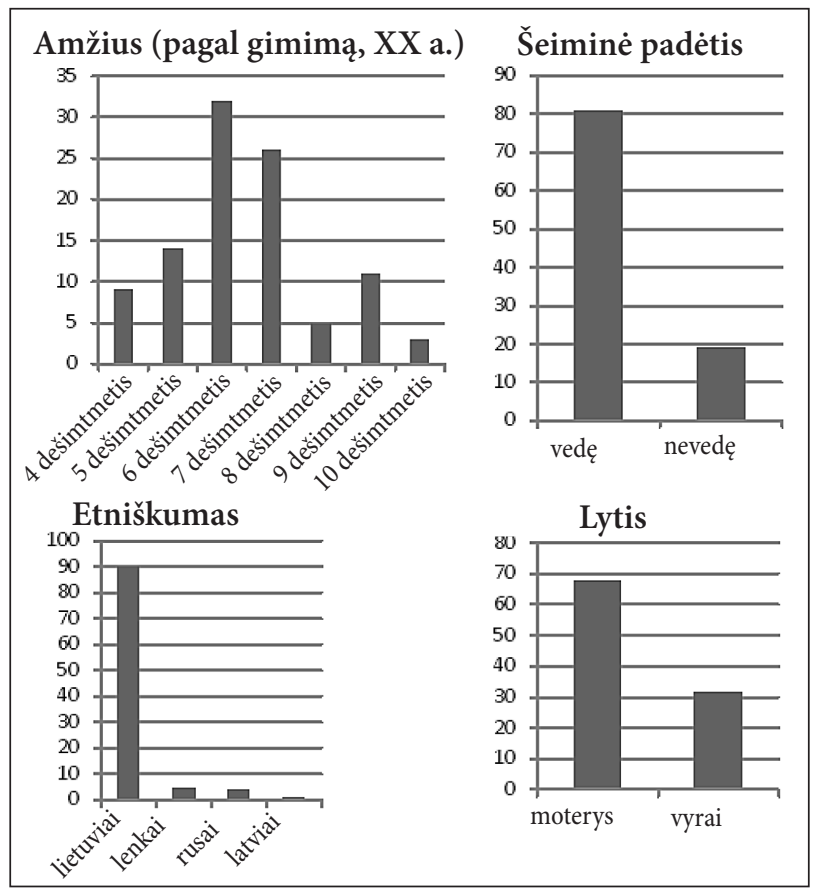

Pav. Lauko tyrimų respondentų demografiniai duomenys (proc.)

(1) Vilniaus edukologijos universiteto (LEU), Istorijos fak. studentai: Andrius Jurgaitis, Aldona Januškevičienè, Andžej Labul, Aušra Petrauskaitė, Daiva Razmukaitė, Eugenijus Bakasėnas, Kristina Poliakutè, Laura Laniauskaitė (2002 m., apklausti 32 vilniečiai).

(2) Straipsnio autorès 2012-2015 m. lauko tyrimai (33 aprašai); LEU Istorijos fakult. studentų Mariaus Varvuolio ir Hario Simo Petrausko (apklausta 20 vilniečių) 2013 m. surinkta medžiaga. 


\section{MODERNIOSIOS ŠVENTĖS STRUKTŪRA XX A.}

Bendrąja prasme šventès struktūra mokslininkų dažnai buvo suvokiama kaip organiška, natūrali ir kartu interpretacinè. Pasak Alessandro Falassi (1987), dauguma renginių laikosi ritualo struktūros, kuri yra bendrų veiksmų ar komponentų seka. Jo teigimu, ši struktūra retai kada buvo sąmoningai organizatorių suplanuota, greičiau organiškai ar nesąmoningai išaugo kaip atsakas į pagrindinius žmogaus poreikius ir tikèjimą (cit. pagal [7, 3]). Susiklostę pagrindiniai struktūriniai elementai išlaikomi ir kuriant naujas šventes, tačiau kiekvienos modernios šventès formalioji dalis turi scenarijų, programą, numatytas veiksmo vietas ir laiką, dalyvius. Bendra modernių švenčių struktūra sudaryta taip, kad įtrauktų kuo daugiau dalyvių, patrauktų visų dèmesį, populiarintų šventę. Remiantis modernių švenčių aprašymais, reportažais apie jas medijoje (plačiau [21]), buvo sudarytas šventès modelis: a) susirinkimas, b) mišios (sovietmečiu Lietuvoje nepraktikuotos), c) apdovanojimai, d) eisena ar demonstracija, e) kapų lankymas, f) koncertas ar kitas linksmas renginys. Skirtingu politiniu laikotarpiu skyrèsi ideologinis ir vizualinis turinys: demonstracijų šūkiai, apipavidalinimas, švenčių „kaltininkų“ apdovanojimai ir pan. Profesinès šventès, ypač tiesiogiai susijusios su valstybės institucijomis, atitiko šị modelį, nors ne visų profesijų šventèse praktikuotos eisenos. Kitoms profesijoms taikytas paprastesnis modelis: iškilmingas posėdis ir

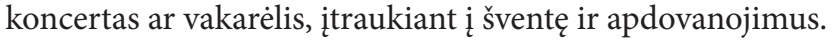

Dar tarpukario Lietuvoje per katalikų šventes buvo paminimi atskirų veiklų žmonės kaip šventųjų globotiniai: Angelų sargų - policijos pareigūnai, Florijono - gaisrininkai (šiose šventėse atitinkamų profesijų nariai dẻkoja už globą Angelams sargams, šv. Florijonui). „Laiškuose lietuviams“ [3] aprašoma tokia šventės struktūra: „Lietuvos policija angelus sargus pasirinkusi savo globejjais, užtat Angelų Sargų diena Lietuvos policijos buvo kasmet labai iškilmingai švenčiama. Ypač Kaunas sutraukdavo daug ịvairių rūšių policijos, kuri organizuotai su savo orkestru žygiuodavo ị Kauno baziliką pamaldoms, kurios būdavo laikomos už mirusius policijos pareigūnus. Pamaldos būdavo baigiamos galingu „Te Deum laudamus", dèkojant Dievui už pagalbą, ir Tautos himnu, ryžtantis ir toliau dirbti Lietuvos gerovei. Po pamaldų Rotušès aikštėje ịvykdavo paradas, o paskui būdavo žygiuojama ị Ąžuolyną, kur būdavo atliekama turtinga meninè programa." Panašus scenarijus buvo ir kariuomenès dieną, ugniagesių atskirų kuopų ịsteigimo dienos proga, net Motinos dieną ir kitomis progomis.

Sovietinèse respublikose, „kuriant naują socialistinę visuomenę“, buvo pertvarkytas švenčių kalendorius, atsiribojama nuo bažnyčios. Sovietinès masinès šventès organizuotos centralizuotai, jos turejo scenarijus su numatytais šventės uždaviniais, nusistovejusiu šablonu, standartu, ir tai lèmé pastovų ritualą [27, 63]. Masinių švenčių standartas taikytas ir nemasinèms šventėms, minejjimams. Dauguma profesinių dienų Lietuvoje, kaip ir kitose sovietinèse respublikose, buvo ịvestos valdžios institucijų, kad pakeltų darbinị sąmoningumą, skatintų siekti aukštų darbo rezultatų. T. Ščepanskaja pamini, kad susirinkimuose dažnai dalyvaudavo kolegos iš kitų organizacijų, vakare pagal programą buvo apdovanojami „geriausi šios profesijos“ ar socialistinio lenktyniavimo nugalètojai, priimami kolegos naujokai.

Posovietmečio Lietuvoje oficialiųjų profesinių švenčių, globojamų ministerijų, organizuojamų ịstaigų administracijų, formaliosios struktūros dažnai yra panašios: lankomos šv. Mišios, skirtos jų globejjui, skamba oficialūs sveikinimai, apdovanojami nusipelnę darbuotojai, kai kurie rengia iškilmes su pasirodymais mieste, kiti - atvirų durų dienas, konferencijas, parodas, koncertus. Iškilmès mieste pritraukia miesto gyventojus, moksleivius, 
pvz., vandentvarkos darbuotojų [24], ugniagesių [13], karių, policininkų, kartais kitų profesijų (miškininkų, medžiotojų) atstovų organizuojamos profesinès dienos. Teatrai, muziejai, bibliotekos, archyvai savo profesinès dienos proga rengia viešus renginius (atvirų durų dienas, koncertus) visuomenei. Kariuomenès diena tiek tarpukariu, tiek sovietmečiu buvo ir dabar išliko (pasikeitus ideologijai ir propagandos turiniui, pakito ir data bei vizualinè forma) išskirtine svarbia valstybės gynybos institucijos švente. Taigi šventėse profesinis tapatumas demonstruojamas ir patvirtinamas miesto bendruomeniniu (vykstančios viešosiose miesto erdvèse), pasauliniu (tarptautiniu mastu) arba korporatyviniu (uždarose organizacijos erdvèse) lygmeniu.

Tiek Lietuvoje, tiek ir Rusijoje kitų profesijų paminejjimas „šiandien dažniausia yra korporatyvų šventès. Garbės pažymejjimo geriausiam darbuotojui suteikimo ritualas lieka specifiniu profesinès dienos bruožu“ $[6,244]$. Tokios korporatyvinès šventès struktūra paprastai apsiriboja paminejjimu kiekvienos organizacijos susirinkime, kur teikiami apdovanojimai, ir / arba tik neformaliu šventimu, kuris pasireiškia užstale (posovietinėse šalyse), kartais apsiribojama žodiniu pasveikinimu ar el. paštu. Kitose šalyse, pvz., JAV, kai kurias profesines šventes ịprasta pažymėti dovanèlèmis (gẻlèmis, saldainiais, niekučiais), pusryčiais restorane ar suteikiant laisvo laiko. Rusijoje populiaresnès profesinès dienos atskirose vietovėse igauna savitus lokalius bruožus, pvz., kiekviename regione, mieste puoselèjamos savitos statybininkų dienos tradicijos (ne tik priduodami nauji objektai): vieni rengia konkursus ir perduoda pereinamąją vẻliavą ar teikia kitus apdovanojimus, kiti pagerbia statybininkus veteranus, žuvusiuosius kare, treti rengia statybinès technikos paradą mieste, dar kiti „šventina“ statybininkus naujokus [28].

\section{VILNIEČIU DALYVAVIMAS PROFESINĖS DIENOS MINĖJIME}

Lietuvoje sovietmečiu oficialus profesinių dienų minejjimas paliko savo pėdsaką. Vilniuje 2002 ir 2012-2015 m. atliktų lauko tyrimų duomenimis, du trečdaliai apklaustųjų sovietmečiu žinojo ir minejjo savo profesines dienas, o 36 \% iš 2002-ųjų apklausos prisiminè, jog jų šeimos nariai taip pat pažymėdavo savo profesinę dieną. Jau vien tai rodo nemenką šių modernių švenčių efektyvumą anuo metu.

Profesinė diena buvo reikšminga profesinio tapatumo įtvirtinimui: dauguma apklaustųjų îvardijo savo profesines dienas, nors data dažnai nebuvo patikslinta (užsimiršo). Paprastai viešai buvo švenčiama organizacijos titulinès profesijos šventè. Netitulinès profesijos nariai, pvz., ịmonèse dirbusios archyvarès, bibliotekininkès, ekonomistai ir pan., likdavo šios šventès žiūrovais, kartais organizatoriais, bet ne ritualo dalyviais. Būtent netitulinès profesijos specialistams buvo sunkiau ịvardyti savo profesinę dieną. Tiesa, kai kurie pateikejjai, suvokdami, jog sovietmečiu visos profesijos turejo savo minètinas dienas, bet neprisimindami, kada ji buvo ar kaip vadinosi, jas priskyre savaip: vienas apklaustas darbininkas mané, jog jo profesinė diena - tai Gegužès 1-oji (Tarptautinė darbo diena), kitas darbininkas šventė desantininko dieną, o viena moteris kaip savo profesinę dieną ịvardijo Motinos dieną (dirbo virèja).

Sovietmečiu dalyvavimas visuose oficialiuose renginiuose buvo privalomas, išskyrus specifinius atvejus, susijusius su nepertraukiamu darbu. Vis dèlto, $2002 \mathrm{~m}$. apklausos duomenimis, didesnè dalis pateikejų (apie $60 \%$ ) i tokius renginius eidavo savo noru, o likusieji - tik dèl to, kad privalejo. Profesinių dienų bendrąja prasme populiarumas skatino neformalu dienos paminèjimą. Net tai, kad ne visos įmonès, organizacijos rengdavo oficialų šios dienos minejjimą - jų neprisiminè „Spartos“ darbininkai, greitosios pagalbos 
medicinos sesuo, pardavejja, kirpėja, darželio auklètoja, leidybos, ryšių, radijo darbuotojai - nesutrukdè jos paminèti neformaliai su kolegomis. Žinoma, dalis jų neminejjo profesinès dienos (ar neprisiminè). Toks neoficialus šventimas su bendradarbiais, draugais rodo, kad ši šventė bendradarbių kolektyve buvo priimtina, prigijusi. Neformalaus šventimo pagrindinis akcentas buvo užstale $[29,199]$. Štai kaip savo profesinę dieną minèjo vilniečiai mokytojai: „tą dieną pasipuošiam, mokiniai pasveikina. Mokykloje nebuvo vaišių. Ten pat kavos nueini išgerti“ (mot., gim. 1939), ar pagal nuotaiką, spontaniškai nueina ị kavinę su artimesnėmis kolegèmis. Statybininkų dienomis būdavo teikiami garbės „raštai, premijos, garbès lentos ir biškị baliukai būdavo - kolektyvuose“ (mot., gim. 1957), „buvo premijos ir bus išgèrimas" (statybininkas, gim. 1942). Apdovanojimai garbės raštais, ženkliukais, premijos buvo paskata švęsti, kartu stiprino profesinį atsidavimą. Iš $2002 \mathrm{~m}$. apklaustųjų pusė jų sovietmečiu buvo apdovanoti garbès raštais, premijomis (3). Užstalè persikèlė ir už darboviečių, kartais ị šeimos ratą.

$39 \%$ apklaustų vilniečių tvirtino, jog juos (daugiausia mokytojus, ugniagesius, policininkus, statybininkus) šia proga sveikino ne tik bendradarbiai, bet ir draugai, šeimos nariai. Kai kurios profesinès šventès buvo įtrauktos ir ị šeimos šventes. Statybos darbų ịmonès vadovo šeimoje ši diena taip pat buvo švenčiama: kasmet tą dieną jị sveikindavo šeimos nariai, „susėsdavo visi prie šventinės vakarienės stalo. Jis savo ruožtu kaskart kitaip ją pažymėdavo - išvykdavo su kolegomis ị kelionę, pasilepindavo pirtyje“" (Statybininkų profesinė 2012). Kiti taip pat švęsdavo šeimomis: „Mūsų sodyboje suvažiuodavo visi mokytojai su šeimomis, sukaldavo suolus tokius ilgus ir stalus tarp medžių (sode) ir stalai su staltiesėm - kaip per vestuves. Švęsdavo taip šumnai, kad nemoku tau papasakoti. Susinešdavo maistą, gèrimų ten lūždavo - pjankë“ (mot., gim. 1933).

Dabartiniu metu apie $60 \%$ apklaustų dirbančių vilniečių mini profesines dienas (4), dažniausia oficialiai. Tačiau ir tarp oficialiai mininčiųjų profesines dienas yra profesijos atstovų, nepripažįstančių šių švenčių. Dažniausia tai susiję su darbinès veiklos diskomfortu, kurị sukelia nemėgstama veikla, nesusiklostę darbiniai santykiai kolektyve, ignoruojama tiesioginio vadovo nepriimtina vadyba. Kai kurie nedalyvaujantieji oficialiose profesiniu dienų renginiuose (iš apklaustųjų pasitaikẻ bibliotekininkų, medikų, ugniagesių, statybininkų) netapatino savęs su profesionalais („man ši specialybė ne prie širdies“; mot., gim. 1960) ar tituline profesija, kiti netoleravo savo tiesioginès valdžios atstovų vadybos ar laikè, kad oficialūs renginiai skirti valdžiai - „viršininkai su aukštesne valdžia švenčia“ (vyr., gim. 1957). Kai kurie iš šių pateikèjų, būdami šios profesijos atstovais, pažymi tą dieną su draugais, bendradarbiais. Tarp apklaustųjų, nemininčių profesinių dienų, buvo ir tokių, kurie dabar neturi priskirtos dienos (24\%) (finansistai, farmacininkai, brokeriai, prekybininkai; chemikas, ekonomistai, logistika, virèjai) arba dažnai keičia darbovietes.

Taigi profesinès dienos oficialaus šventimo standartas, kuris neišvengiamas ịsitvirtinant ritualui, ir žinomumas (informacija medijoje), paplitimas, kurio išraiška - masiškumas, palaipsniui diversifikavosi, tapo atskirų darbo kolektyvų švente, o kai kurios jų pateko i šeimą. Sovietmečiu privalomas (vilniečių) dalyvavimas oficialiame profesinès dienos minejjime dažnai virto neformaliu užstalès šventimu. Net jei nebuvo oficialios šventès darbovietėje, darbuotojai susitikdavo paminèti šią progą neformalioje aplinkoje. Šiandien

(3) Panašus skaičius ir savo noru šią dieną šventusių pateikèjų, tačiau tie pateikejjai nebūtinai buvo gavę kokius nors apdovanojimus.

(4) Buhalterių, muziejininkų, spaudos, bibliotekininkų, mokytojų, medikų, policijos, ugniagesių, kariuomenès, aplinkosaugos, veterinarijos, kurjerių, energetikų. 
Nepriklausomoje Lietuvoje, pakeitus minejjimų datas, populiariausios profesinès dienos minimos ne tik oficialiai, bet ir neformaliai, šeimose. Nedalyvavimas tokiose šventèse aiškinamas nesusiklosčiusiais kolektyviniais santykiais ar hierarchiniu atsiribojimu.

\section{PROFESINĖS DIENOS-IDĖJOS SUVOKIMAS}

Šventès ideja sukonstruojama parenkant profesinès dienos datą ir ją išplatinant propagandos kanalais. Plačiąja prasme „propaganda yra viešas, instituciškai reglamentuotas, tinklinis, pasikartojantis masių ar socialinių grupių įtikinejjimas. Jis yra susijęs su specialių mąstymo formų konstravimu, ideologinių suvokimo ir vaizduotės schemų indoktrinacija, emocijų ir jausmų stimuliavimu ir valdymu“ $[15,19]$. Oficiali dienos data parenkama tikslingai orientuojantis i politines ideologines to meto vertybes. Jos šiek tiek kito ir sovietmečiu. Kaip pažymėjo Dalia Senvaitytè, nagrinèjusi kalendorinių švenčių diskurso kaitą Lietuvos spaudoje atskirais istoriniais periodais, išskirtinio demesio sulaukè pagrindinès valstybinès šventės bei sovietų armijos atskirų padalinių dienos [17, 112]. Pastarosioms po Stalino mirties demesio buvo skiriama mažiau [17, 118], o L. Brežnevo epochoje daugiau dèmesio sulaukẻ spaudos, geležinkelininko, statybininko dienos [18, 125]. Praplečiant šias ¡žzvalgas buvo apžvelgta bibliografinè rodyklè „Liaudies tradicijos“ [12] (5) ir pastebèta, jog iš profesinių dienų (6) daugiausia dèmesio skirta „Spaudos dienai. Radijo dienai“ - 39-ios ir „Kosmonautikos dienai“ - 27-ios nuorodos (7). Be karinių profesijų, atskirai paminètos mokytojo, statybininko (po 10 nuorodų), geležinkelininkų (8) dienos. Taigi dèmesys sovietinėje Lietuvoje, galima sakyti, pirmiausia buvo sutelktas ị kariuomenès, informacinių, ugdomųjų ir infrastruktūros plètros profesijų atstovus.

Sovietinės propagandos turinys švenčių proga buvo standartinis. D. Senvaitytè rašo:

„Visų naujai suformuotų Sovietų Sąjungos švenčių forma ir eiga, taip pat ir jų vaizdavimas spaudoje iš esmès buvo vienodi. <...> Šventinei dienai priartejus, pasirodydavo publikacijų, kuriose būdavo primenama šventès esmè, prasmè, jos istorinès atsiradimo sąlygos. Šventei praejjus, būdavo gana smulkiai aprašoma Maskvoje ir Lietuvoje, atskiruose jos miestuose ir miesteliuose vykusių šventinių renginių eiga. Visos didžiosios sovietų šventès buvo pradedamos svarbių valdžios atstovų kalbomis, kuriomis reikšta padèka komunistų partijai ir jos lyderiui“" $[17,106-107]$.

Taigi profesinių dienų švenčių proga buvo akcentuojama: sovietinės institucijos įsteigimo data, rodanti prasidejusị „kokybiškesnị etapą“ profesijos istorijoje, ir komunistų partijos svarba šiame kelyje; pasiekimai profesijoje ir pažangiausių darbuotojų pagerbimas.

Po sovietmečio pasikeitè profesinių dienų minejjimo datos, pasikeitė ir jų ideologinè propaganda. Daugiau dèmesio skiriama naujos datos reikšmei pabrèžti (institucijos ¡̇kūrimas, svarbaus ịvykio, reikšmingo tai progai, jai priskirto šventojo globejjo aprašymas ar pan.). Tai - politinę ir konfesinę ideologiją ịtvirtinančios datos. Kai kurios datos ir sovietmečiu buvo nepastovios, ypač tos, kurios derintos prie tradicinių švenčių, pvz., derliaus šventės, ar nesusietos su konkrečiu ịvykiu (statybininkų - svarbių objektų pridavimas), ir visai naujos, realiai neišreiškiančios jokios politinės ideologijos (medikų, kultūros

(5) Straipsniai, repertuaras - eilèraščiai, gaidos, plokštelès. Analizei naudojamos tik straipsnių nuorodos.

(6) Bibliografija suskirstyta ị tris pagrindines grupes: 1) valstybinès, 2) visaliaudinès, masinès ir 3) buitinès šventès. Profesinès dienos ịtrauktos ị plačiausią antrają, visaliaudinès, masinès šventės, grupę.

(7) Palyginimui: valstybinès dienos, turèjusios daugiausia nuorodų - Pergalès diena (30), Tarptautinè moters diena (20). 
darbuotojų). Po sovietmečio jos nedaug tepakito - vietoje sekmadienio švenčiama to paties savaitgalio šeštadienị (statybininkų, miškininkų ir kt.). Profesinių dienų minèjime daug dèmesio skiriama nusipelniusių tos profesijos narių pagerbimui, apdovanojimams ir apskritai pačios profesijos pasiekimams moksle, jos nuopelnams visuomenès gerovei ir kt.

Pasiteiravus, kam skirtos šios progos, vyresnieji pateikejai, kalbėdami apie sovietmetí, prisiminè esminius propagandos dalykus ir juos pakartojo arba, kaip ir jaunesnieji, vadovavosi abstrakčia samprata, kita dalis pateikejų neturejjo atsakymo. Daugiausia buvo manančių, jog ji skirta geriems darbuotojams pagerbti, profesionalams ịvertinti: „ta švente norèta pagerbti žmones, dirbančius ši darbą, kuris yra sunkus ir atsakingas“ (med. sesuo, gim. 1954); "pagarba medikams dèl mokslinių pasiekimų ir medicinos raidos“ (medikè, gim. 1957); „pagerbti mokytoją kaip ugdantị ateinančią kartą“ (mokytojas, gim. 1960); paskatinti darbuotojus siekti aukštų rezultatų: „,norint pagerbti šios profesijos atstovus bei norint paskatinti darbuotojus siekti pasirinktos specialybės tobulumo“ (spaudos darbuotoja, gim. 1968). Dalis pateikejų profesinių dienų atsiradimą siejo su sovietine politika ir suvokè kaip formalias ir tuo metu privalomas: „priežastys ir tikslai - tikriausiai sovietinio gyvenimo iš TSRS trafaretinis kartojimas" (architektas, gim. 1944); mašinų gamybos sektoriuje dirbęs pateikejjas sakè: „kiek suprantu, tai buvo CK nutarimas“ (inžinierius, gim. 1951), o vaikų darželio auklètoja prisiminè šūkị: „vaikų auklèjimas šviesiam rytojui“ (mot., gim. 1958). Kiti ị politinị aspektą nekreipe dèmesio ir manė, jog profesinė diena yra proga susipažinti, pabendrauti didelio kolektyvo darbuotojams: ,jungianti žmones, dirbančius įvairius darbus komunalinio ūkio sistemoje“ (tarnautoja, gim. 1941).

Atsakyti, kodèl minèjimui paskirta būtent ši data, galèjo tik vienas kitas pateikèjas. Radijo technikas, dirbęs sovietmečiu, teisingai sakè, kad tą dieną „Popovas išrado radiją“ (vyr., gim. 1954), dabar dirbantieji spaudos darbuotojai dažnai įvardijo spaudos atgavimo progą, tačiau dauguma nežinojo mokytojo, teatro ar kitos populiarios dienos datos priskyrimo profesijai preteksto. Lengviau buvo įvardyti institucijos įsteigimo dieną ar sutapatintą su šventojo globejo diena. Mokslininkai pažymejjo, kad žmonės užmiršta šventès kilmès istoriją [10,98], o išgalvoti nauji kilmès mitai, išreiškiantys politinio elito ideologijas, dalyviui dažniausia nèra reikšmingi. Tai leidžia teigti, jog datos, žyminčios profesijos pagrindinę idejją, dažniausia nèra pagrindinis akstinas minèti profesinę dieną ar svarbi tapatinimosi prielaida.

\section{IŠVADOS}

Modernios šventès struktūra - susirinkimas, mišios, eisena; pasižymejjusių darbuotojų viešas pagerbimas; koncertas ar vakarèlis - išliko tiek sovietmečiu (tik vietoje mišių - mitingas), tiek dabar. Kiek ilgai išliks šis struktūros modelis, kaip jis kis - neaišku, tačiau šventimo būdų diversifikacija tarp profesijų pamažu vyksta. Tikètina, jog ši minèjimų diversifikacija, atsiradusi po standartizuoto šventimo, leidusio apimti platesnị profesijos narių ratą, labiau įtvirtino šventę. Ji palaikoma ne tik oficialios struktūros - dienos neformalus paminèjimas, t. y. tarp bendradarbių ir ypač šeimos rate, rodo profesinès dienos gyvybingumą.

Modernios šventès, profesinès dienos įsitvirtinimui svarbų vaidmenį atliko ir atlieka propaganda, padejusi inkorporuoti ir, permodeliavus sovietmečiu propaguojamas idejjas $\mathfrak{i}$ tarpukario ar nūdienos svarbias idejjas-datas, išlikti dienos minejjimui. Nors minèjimų datos stipriai susaistytos su ideologija, istorine atmintimi, tačiau tyrimas rodo, kad dabar dauguma visiškai neakcentuoja, nežino ir nesidomi, kokia proga buvo pasirinkta minejjimo data. 
Galima teigti, jog profesinis tapatumas šventèse stiprinamas internalizuojant vertybes: pasididžiavimą, garbę, pareigą visuomenei ir pan., o idejjiniai (politiniai, konfesiniai) aspektai pateikejų pasisakymuose nesureikšminami arba nefiksuojami ir yra nesvarbūs.

Gauta 20151119

Priimta 20160914

\section{Literatūra}

[1] BELL, Catherine. Ritual. Perspectives and Dimensions. New York, Oxford: Oxford University Press, 1997.

[2] CASTELLS, Manuel. Tapatumo galia. Kaunas: Poligrafija ir informatika, 2006.

[3] DIRKIS, P. Angelai Sargai. Laiškai lietuviams, 1958, Vol. 9, spalis [interaktyvus] [žiūrèta 201308 03]. Prieiga per internetą: <http://laiskailietuviams.lt/index.php/1958m-9-spalis/1206-angelai-sargai>.

[4] EK-NILSSON, Katarina. New Political Agendas: the National Day Celebration in Sweden. In: Politics, Feasts, Festivals. Eds. Gábor Barna, István Povedák. Szeged: Department of Ethnology and Cultural Anthropology, 2014, p. 81-85.

[5] FOURNIER, Laurent Sébastien. Intangible Cultural Heritage and the Birth of International Festival. Politics. In: Politics, Feasts, Festivals. Eds. Gábor Barna, István Povedák. Szeged: Department of Ethnology and Cultural Anthropology, 2014, p. 111-120.

[6] FROLOVA, Alexandra. Modern Holiday Calendar of the Russians. Issues in Ethnology and Anthropology, 2013, Vol. 8, No. 1, p. 239-257.

[7] FROST, Warwick; LAING, Jennifer. Introduction: From Pre-modern Rituals to Modern Events. In: Rituals and Traditional Events in the Modern World. Eds. Jennifer Laing, Warwick Frost. New York, London: Routledge, 2015, p. 1-20.

[8] GIEREK, Bożena. Interference of Politics in Celebrating "Dożynki"-The Festival of Harvest in Poland in 1950s. In: Politics, Feasts, Festivals. Eds. Gábor Barna, István Povedák. Szeged: Department of Ethnology and Cultural Anthropology, 2014, p. 171-192.

[9] HELSLOOT, John. Vernacular Authenticity: Negotiating Mother's Day and Father's Day in the Netherlands. In: Reframing Dutch Culture. Between Otherness and Authenticity. Eds. Peter Jan Margry, Herman Roodenburg. Ashgate Publishing, Ltd., 2007, p. 203-224.

[10] HELSLOOT, John. Valentino dienos triumfas Nyderlanduose po penkiasdešimties metų. Lietuvos etnologija: socialines antropologijos ir etnologijos studijos, 2008, Nr. 8(17), p. 97-116.

[11] HUGOSON, Marlene. "Instant Tradition": The Introduction of the Swedish Easter Tree. Folklore, 2006, No. 117, p. 75-86.

[12] Liaudies tradicijos. Rekomenduojamos literatūros rodyklè ir metodinè medžiaga. Sudarè V. Jurgaitis, E. Lagauskienė, P. Mikelinskaite, E. Juodis, A. Subatniekas ir V. Aputienė. Vilnius, 1967.

[13] KUIZINAITĖ, M. Ugniagesių kasdienybę vilniečiai stebèjo lyg spektakli. Lietuvos rytas, 2005, gegužès 5, priedas „Sostiné“, p. 8.

[14] KUODYTĖ, Rūta; MARDOSA, Jonas. Sovietmečio šventès ir tradicijos. Iš: Apie metodikq ir metodines priemones. Sudare J. Mardosa. Vilnius: VPU leidykla, 2002, p. 129-133.

[15] MAŽEIKIS, Gintautas. Propaganda ir simbolinis mąstymas. Kaunas: Vytauto Didžiojo universitetas, 2010.

[16] PAPP, Melinda. Molding of a Rite of Passage in Urban Japan: Historical and Anthropological Perspectives. Urbanities, 2013, Vol. 3, No. 1, p. 61-82.

[17] SENVAITYTĖ, Dalia. Kalendorinių švenčių diskursas sovietinëje Lietuvos periodikoje. I dalis: 1945-1964 metai. Lituanistica, 2013, t. 59, Nr. 2(92), p. 101-121. 
[18] SENVAITYTĖ, Dalia Kalendorinių švenčių diskursas sovietinėje Lietuvos periodikoje. II dalis: 1964-1990 m. Lituanistica, 2014, t. 60, Nr. 2(96), p. 118-133.

[19] Statybininkų profesinè šventė - atmintina diena kalendoriuje. Statybu žinios, 2012, Nr. 8(62), p. 7 [interaktyvus] [žiūrèta 201311 05]. Prieiga per internetą: <http://www.statybininkai.lt/>.

[20] SULLIVAN, William. Work and Integrity; The Crisis and Promise of Professionalism in North America. New York: Harper Collins, 1995.

[21] ŠIDIŠKIENĖ, Irma. Profesinès šventès tyrimų ir medijų lauke. Lietuvių katalikų mokslo akademijos metraštis. Vilnius, 2014, t. 38, p. 225-237.

[22] THEODOSSOPOULOS, Dimitrios. Introduction, Laying Claim to Authenticity: Five Anthropological Dilemmas. Anthropological Quarterly, 2013, Vol. 86, No. 2, p. 337-360.

[23] van der ZEIJDEN, Albert. Public Folklore and the Construction of a Regional Identity in Newly Reclaimed Dutch Polders. In: Reframing Dutch Culture. Between Otherness and Authenticity. Eds. Peter Jan Margry, Herman Roodenburg. Ashgate Publishing, Ltd., 2007, p. 59-81.

[24] Vandentvarkos darbuotojų šventè vilniečiams, 2005 [interaktyvus] [žiūrèta 201309 20]. Prieiga per internetą: <http://www.verslobanga.lt/lt/spaudai.full/42789af749d56>.

[25] WYNIA, Matthew K. The Role of Professionalism and Self-regulation in Detecting Impaired and Incompetent Physicians. The Journal of the American Medical Association (DJAMA), 2010, No. 304(2), p. 210-212.

[26] ZOLA, Lia. Ritual Continuity and "Failed Rituals" in a Winter Masquerade in the Italian Alps. Journal of Alpine Research / Revue de géographie alpine, 2011, 99/2, p. 1-9 [interaktyvus] [žiūrèta 201309 10]. Prieiga per internetą: <https://rga.revues.org/1443>.

[27] ГАЛИНОВСКАЯ, Ю. Праздник по-советски: официальная праздничная культура в Беларуси. In: Десоветизация в контексте трансформации белорусского общества. Ред. В. Мацкевич. Вильнюс: Центр европейской трансформации, 2012, с. 41-67.

[28] День строителя: история праздника, n. d. [interaktyvus] [žiūrèta 201308 12]. Prieiga per internetą: <http://www.vashdom.ru/articles/rockwool_4.htm>.

29] ЩЕПАНСКАЯ, Т. Б. Сравнительная этнография профессий: повседневные практики и культурные коды (Россия, конеи XX - начало XXI в.). Санкт-Петербург: „Наука“, 2010. 
IRMA ŠIDIŠKIENE்

\section{Professional identity-building practice: a professional day in Vilnius}

Summary

The aim of the paper is to analyse the significance of the celebration of a professional day for the strengthening of professional identity. Comparing celebrations of professional days during the Soviet times and nowadays, we will have to deal with two tasks: first, to observe the gradual change of the official ritual, and maintaining of the special day through informal practices of the community. In order to check how important the official idea of the festival is to informal celebration, the second task must be addressed, i. e., whether the propaganda of the professional day helps to internalise and assimilate the idea of the special event.

The research has been conducted by means of analysing the (Soviet and current) media coverage revealing the idea and process behind the official celebration of professional days. Material was collected from structured interviews which revealed the informal relationship of the residents of Vilnius with the festival discussed.

Application of a unified structure of a modern festival to professional days enabled them to be visible in public, and to get established among co-workers. Their manifestation on the informal level, i. e., among colleagues, and especially in the family circle, indicates the validity of a professional day. When the dates of professional days were changed in independent Lithuania, the most popular festivals have been celebrated since. A failure to attend such celebrations is justified by hierarchical distancing, by poor relationships with co-workers, or by inability to identify with the title profession at workplace.

It could be claimed that professional identity is being strengthened by internalising certain values: pride, honour, a sense of duty to the public, etc. As for the dates/ideas which are closely tied to the (political, confessional) ideology or historical memory, the respondents do not give them much prominence. Scholars note that people tend to forget the history of the origin of a festival $[10,98]$. The invented new myths of the origin, which convey ideologies of the political elite, are usually insignificant to a participant.

Keywords: a professional day, professional identity, date/idea of a modern festival, structure of a modern festival 